\title{
Externalities by Automobiles and Fare-Free Transit in Germany - A Paradigm Shift?
}

\author{
Karl Storchmann \\ Yale University
}

\begin{abstract}
To mitigate automobile-caused externalities, several European cities have introduced fare-free transit schemes. Best known are the plans introduced in Hasselt, Belgium, and Templin, Germany. The staggering increases in ridership in both cities seem to prove the overwhelming success of this policy. In addition, a study carried out for the German Federal Ministry of Transportation scrutinized the program in Templin and found that a positive net effect is likely and fare-free transit is a viable policy to curb automobile externalities. Fare-free schemes are based on the economic theory of the second-best. Automobile users should be encouraged to shift to environmentally friendly transit. An undesired side effect, however, may be the increase in the demand by former transit users and the attraction of pedestrians and bicycle riders. In Templin, the side effect was prevailing, whereas the shift from automobile to transit was only minimal. The positive net benefit was due to the reduction in fatalities and casualties: Since pedestrians and bicycle riders belong to the most endangered road users, every decrease in these modes will lead to a reduction of automobile-caused costs. The undesired side effect thus became the main effect.
\end{abstract}




\section{Introduction}

The growth in transportation with respect to number of trips, passenger miles and vehicle miles is second to none not only in the United States but in most developed countries. From 1960 to 2000 passenger miles by automobiles and transit have risen by about 250 percent-from 1,276 billion to 4,442 billion. Due to decreasing occupation rates, vehicle miles have even grown from 587 billion to 2,536 billion-more than 330 percent. Most countries in Western Europe have experienced the same level of transportation growth in recent decades. Even if this increase is losing in dynamics, saturation is not in sight. Most, if not all, of this growth is driven by the automobile. Public transportation barely benefits from this development, resulting in little or stagnating growth rates. However, the mounting costs of externalities caused by automobile travel (e.g., accidents, traffic jams, environmental problems), suggest a modal shift from cars to public transportation as an increasingly desirable goal. Given the immense spatial and temporal concentration, this is particularly true for the commuter streams during peak hours.

Several policy options can initialize and support this modal shift. Aside from regulatory instruments, such as the reduction of parking opportunities or an increase in the supply of public transportation services, economists focus on the change of relative prices. In general, they distinguish transit-supporting policies (pull policies) from schemes aimed at constraining automobile use (push policies). The first policy is considerably more popular with the public as well as transit companies.

Against this background, the long-time muted demand for fare-free transit is awakening. For a long time, it seemed as though the intense discussion of the 1970s about free transit would be on the decline and eventually disappear. However, recent developments have shown that a renaissance is imminent if not already flourishing. Several environmental groups (e.g., Greenpeace and Robin Wood) and political parties, such as PDS ${ }^{1}$ (the successor of the former east German socialist party) have put fare-free transit on their agendas.

At the same time the number of European cities that have adapted fare-free transit schemes is growing steadily. One of the most stunning examples of the plan's success is Hasselt, Belgium. Since the abolishment of all transit fares for the entire urban area in July 1997, ridership has increased by more than 1,000 percent (City of Hasselt 2000). The reasoning behind the idea of fare free transit is the following: A considerable modal shift from car travel to public transportation makes the 
construction of new roads unnecessary, and existing roads can even be built back. The resulting savings more than offset the increasing subsidies for transit services, thus leading to a positive financial net effect. Following the attractive example set by Hasselt, many cities, especially in Germany, hope to resolve their financial and transportation issues through the introduction of fare-free transit schemes. The German town of Templin is another positive example of fare-free transit. Since 1997 the purchase of a ticket has been obsolete in several small German cities, including Templin (14,000 inhabitants). A study carried out for the German Federal Ministry of Transportation investigated and evaluated the benefits of fare-free schemes using Templin as reference (Keuchel et al. 2000). Overall, the results are fairly positive and encouraging - the benefits outweigh the costs by far. This could lead to a dominance of pull policies over push policies. Is this the beginning of a paradigm shift in policies aimed at solving environmental problems of transportation?

This article describes whether and to what extent countrywide fare-free transit schemes - aside from small pilot projects-are able to induce a large-scale modal shift from car travel to public transportation and, therefore, mitigate externalities. After presenting the theoretical background, the article discusses the experiences in Templin from an economist's point of view. The article ends with a summary and an overall assessment of fare-free transit schemes.

\section{Second-Best Pricing Solution}

From an individual firm's point of view, it is evident that the implementation of fare-free schemes always entails financial deficits for the transportation company: There is no payment in return for a service anymore. In fact, the financial situation of public transportation companies is traditionally precarious even without farefree schemes. To provide and maintain an effective public service of an appropriate size, the mobilization of considerable subsidies has been required for decades. In the United States the Federal Transit Administration (FTA) collects and disseminates data on the state of mass transportation via the National Transit Database (NTD) program. As reported by the FTA (2002), total federal, state, and local subsidies have risen from $\$ 0.9$ billion in $1970^{2}$ to about $\$ 25.6$ billion in 2002 . Subsidies for mass transit in Germany, as reported in "Bericht über die Folgekosten des öffentlichen Personennahverkehrs" (Deutscher Bundestag 1997), account for about $\$ 6$ billion (Ratzenberger 1997; WIBERA 1996; Storchmann 1999). Often, the level of subsidies is not only regarded as an indicator of a lack of efficiency, in fact, they are deemed as the main cause of ineffectiveness (Pucher et al. 1983). This 
may be correct for the vast majority of private companies. Mass transportation companies, however, are mainly public companies and thus pursue a different goal. In general, they do not aim at the goal of profit maximization but want to maximize welfare; in financial terms only is cost recovery desirable (e.g., Bös 1986; Turvey 1971). Therefore, the term "efficiency" focuses on the questions:

- What level of service should be provided?

- How should it be priced?

Since the early 1970s, several welfare-oriented models have been developed to determine the optimal service and price level for mass transit under first-best conditions (e.g., Mohring 1972; Turvey and Mohring1975; Jansson 1980). ${ }^{3}$ All of these studies refer to the term "social cost" which, aside from the companies cost, particularly accounts for time costs of third parties (externalities). On the base of first-best marginal pricing rules, a deficit can, in fact, be compatible with the achievement of the welfare optimum. However, since costs should be borne by those transit passengers who cause them, peak fares should be significantly higher than off-peak fares. Whereas marginal costs caused by off-peak passengers tend to zero, an incremental peak passenger requires considerable resources. By law, the size of capital stock and staff has to be dimensioned according to the transportation needs in rush hours.

Under first-best conditions, service and price level are calculated and optimized for each mode of transportation separately. This solution is welfare optimal only if substitute modes to public transportation follow the same rules and also charge first-best prices. However, these conditions are not always readily fulfilled. If a relevant substitute mode deviates from the marginal cost-pricing rule due to imperfect markets or externalities, transit fares should deviate from this rule as well in order to guarantee a welfare maximum. This new optimal fare is called the "second-best optimal" price. The theory of the second best, thus, aims at answering the question whether and to what extent a deviation from first-best prices can be beneficial to reach welfare gains. In its general form, the second-best theory was first introduced in the 1950s by Lipsey and Lancaster (1956/57); later it was applied in several specific fields. Given the extent of automobile-caused externalities, such as congestion and environmental damage, and the fact that public transportation and automobile travel are relatively close substitutes, the consideration of secondbest arguments for mass transit pricing is almost compelling. ${ }^{4}$ This leads to the question whether public transportation should deviate from first-best pricing 
rules and charge lower (deficit-causing) second-best fares. In this context, the introduction of fare-free transit has been discussed since the early $1970 \mathrm{~s}^{5}$

In its simple version, the second-best approach distinguishes only between the two modes of public transportation ( $t$ ) and automobile (a). The second-best optimal fare is then calculated according to the following formula (Gómez-lbáñez 1999):

$P_{t}=M C_{t}-\left[\left(\frac{E_{a t}}{E_{r}}\right) \cdot\left(\frac{Q_{a}}{Q_{r}}\right) \cdot\left(P_{s}-M C_{a}\right)\right]$

where:

$P_{r^{\prime}} M C_{r}$ and $Q_{t}$ stand for fare, marginal cost, and quantity consumed of transit services.

$P_{a^{\prime}} M C_{a^{\prime}}$ and $Q_{a}$ denote the respective variables for automobile travel.

$E_{t a}$ denotes the cross-price elasticity of automobile travel in response to changes of transit fares.

$E_{t}$ is the own-price elasticity of public transportation.

According to the logic of second-best pricing, the reduction of transit fares pays as long as the marginal reduction cost of automobile-caused externalities by converting automobile users to mass transit is smaller than the actual marginal damage. Or more concretely, subsidies to public transportation are worthwhile as long as every additional dollar avoids a marginal damage higher than a dollar. Thus, the optimal amount of the subsidy is reached when marginal damage and marginal reduction costs are equal.

As can be seen from equation (1), the second-best optimal transit fare equals marginal cost $\left(M C_{t}\right)$ minus the term in brackets. Only if the term in brackets is equal to zero, should public transportation charge marginal cost prices (i.e., firstbest prices); otherwise a deviation is worthwhile. Given that automobile-caused externalities are predominantly negative, this "deviation" translates into a fare reduction. This reduction will be larger the more the cross-price elasticity dominates the own-price elasticity; that is, the easier it is to attract automobile users compared to transit users. On the one hand, fare reductions are inefficient and useless if the cross-price elasticity is equal to zero. In this case not a single car driver will be attracted by low transit fares. On the other hand, an automobile domi- 
nated modal split as well as high marginal externalities per passenger mile $\left(M C_{a}>P_{a}\right)$ induce low second-best transit fares.

The actual amount of the fare reduction is dependent on the value of each variable, i.e., the price and cross-price elasticities, the current modal split, and the respective marginal costs. In general, any transit fare is possible, including zero fares or even negative fares. However, a second-best optimum of exactly zero requires a very specific constellation. Hence, the economic justification of a farefree transit regime demands high empirical requirements. General fares of zero, therefore, are to be taken as rule of thumb rather than as an exact second-best optimal outcome. They are not much more than an approximation to a secondbest optimum.

Generally, equation (1) can be applied for different service times, such as peak and off-peak. However, in this case we are able to consider intermodal substitution between automobile and transit for one service time only (peak or off-peak). For instance, a shift from peak-automobile travel to off-peak transit cannot be depicted. To account for intertemporal interrelations, more complex approaches have been developed (Glaister 1974). Empirical studies, however, suggest that modal substitutions clearly prevail over temporal substitutions (Table 1). The odds to turn peak into off-peak travel-regardless of the mode-tend to be close to zero.

Table 1. Transit Fares and Price Elasticities

\begin{tabular}{lcccc}
\hline & \multicolumn{2}{c}{ Automobile } & \multicolumn{2}{c}{ Transit } \\
\hline & Peak & Off-peak & Peak & Off-Peak \\
Peak & 0.03 & 0.00 & -0.35 & 0.04 \\
Off-peak & 0.00 & 0.02 & 0.03 & -0.87 \\
\hline
\end{tabular}

Source: De Borger et al., 1996; Glaister and Lewis, 1978. 
From a theoretical point of view, second-best prices, and thus fare-free transit, is associated with several implications. First, a change in relative prices gives the necessary incentive for a modal switch from automobiles to environmentally friendly public transportation; this is the intended substitution process. Second, they will also induce additional demand by former transit users. This undesired side effect will be the greater the more the own-price elasticity dominates the cross-price elasticity. Since transit is a substitute not only to passenger cars but also to nonmotorized modes, a shift of bicyclists and pedestrians to transit is likely. Third, fare-free transit is likely to generate new travel demand (induced traffic). Finally, fare-free transit will entail an income effect: Consumers who use mass transit and automobiles will face an increase in real income. This can lead to more automobile travel.

According to empirical studies, there is only a very small potential for shifting automobile travel to public transportation. As shown in Table 1, cross-price elasticities of car travel with regard to transit price changes are almost zero. For instance, a decrease in peak fares by 10 percent will lead to an increase in peak ridership by 3.5 percent. Automobile travel, however, will be reduced by only 0.3 percent. Hence, the vast majority of new riders consists of former transit users, pedestrians, bike riders, or is newly induced traffic. There will also be a moderate intertemporal shift from off-peak transit to peak transit.

In addition, increasing ridership will require adjustments in the capital stockregardless whether this is due to shifted or induced demand. This will entail an impact on the marginal production cost, which as $M C_{t}$ is an implicit part of equation (1). However, investment decisions are not to be made only using a partial cost-benefit analysis. In fact, if alternative applications were considered, one has to account for opportunity costs. Given market imperfections within one segment, the second-best optimum should not be determined partially but rather for the overall economy; peripheral piecemeal policy and second-best optimum are incompatible (e.g., Bös 1986). Otherwise, the reference to second-best solutions could justify any suspension of competition.

\section{Experience in Templin}

Templin, a health resort town with about 14,000 inhabitants, is located in east German Brandenburg, about 60 miles northeast of Berlin. Its bus system in relatively small. There are two main lines and two auxiliary lines. The "fare-free bus service" project was launched on December 15, 1997. Since then the usage of 
public transportation has been free for everybody. Financial means are provided by the city of Templin, the Land Brandenburg, the county, and the local transportation authority Uckermärkische Verkehrsgesellschaft $\mathrm{mbH}$. The declared goal of this policy was to reduce automobile usage and its main externalities such as noise, pollution, and the risk of accidents (Stadt Templin 2000).

Within a year after the transit scheme's introduction, transit ridership increased by almost 750 percent - from 41,360 to 350,000 passengers per year. Two years later, in 2000, ridership was above 512,000-almost 13 times its original amount (Stadt Templin 2000).

A study carried out on behalf of the Federal Ministry of Transportation investigated transit ridership before and after the fare-free program by surveying passengers (Keuchel et al. 2000). The study found that the vast majority of new transit riders are children and adolescents. This agrees with experiences in fare-free transit programs launched more than 30 years ago. As early as 1973, Baum reported on "additional demand accruing from useless and senseless journeys by children" (Baum 1973). A similar "adverse selection" occurred in early fare-free programs in the United States. Aside from joy-riding kids, transportation authorities were especially worried about increasing vandalism. The best-known U.S. fare-free project was launched in 1989 in Austin, Texas. It was abandoned after only 15 months. One of the issues was the increase in incidents involving intoxicated passengers (Hodge 1994).

When asked what means of transportation would be replaced, most people answered they would substitute public transportation for nonmotorized travel. The study found that 35 to 50 percent of transit passengers would walk less, 30 to 40 percent would replace bicycle rides, and 10 to 20 percent would reduce automobile trips. However, it is unclear whether this refers to the driver or the passenger. Nor is the length of the respective trip mentioned. Hence, conclusions regarding passenger miles cannot be drawn. Using simulation techniques Keuchel et al. evaluated the impact of the program on the modal split. It turned out that ownprice elasticities for the trip purposes school, work, and shopping are significantly higher than those for leisure related trips. ${ }^{6}$ Cross-price elasticities are considerably lower and worth mentioning only for the trip purposes to school or work. This matches empirical results drawn from an econometric transportation model for Germany as a whole (Storchmann 2001). According to these numbers, a moderate modal shift potential can be expected only for school and work trips (see Table 
2). The vast majority of these trips occurs during peak hours which will entail increasing marginal production cost.

Table 2. Price Elasticities of Public Transportation a and Automobile Travelb by Trip Purpose

\begin{tabular}{|c|c|c|}
\hline & \multicolumn{2}{|c|}{ Own-Price Elasticities } \\
\hline \multirow[t]{7}{*}{ Public transportation } & Work & -0.321 \\
\hline & School & -0.121 \\
\hline & Business & -0.052 \\
\hline & Shopping & -0.087 \\
\hline & Leisure & -0.076 \\
\hline & Total & -0.150 \\
\hline & \multicolumn{2}{|c|}{ Cross-Price Elasticities } \\
\hline \multirow[t]{6}{*}{ Automobile travel } & Work & 0.045 \\
\hline & School & 0.136 \\
\hline & Business & 0.001 \\
\hline & Shopping & 0.015 \\
\hline & Leisure & 0.005 \\
\hline & Total & 0.017 \\
\hline
\end{tabular}

a. Comprising subways, tramways, and buses.

b. Measured in passenger kilometers.

Source: Storchmann, 1999.

What are the benefits of fare-free transit for the town of Templin? Could the goal of mitigating private automobile travel be achieved? Keuchel, et al. (2000), distinguish the four benefit components - production, infrastructure, image, and externalities - and quantify the respective effects.

\section{Production}

Generally, fare-free transit schemes make all activities associated with collecting fares unnecessary. Depending on the system, the cost savings can be considerable. However, for small bus systems, as in Templin, these savings can be neglected. Keuchel et al., therefore, assume no cost reduction. On the other hand, all activi- 
ties associated with checking tickets can be abandoned also. In Templin, this leads to cost reductions of $\cdot 5,000$ to $\cdot 10,000$.

It is questionable whether the time spent at bus stops can be reduced by letting passengers board without having to buy a ticket. This would lead to an increase in the velocity and could save considerable cost. Even though this seems to be the case at first glance, we have to account for the increasing number of passengers which could offset any time saving. Given an increase in ridership by more than 1,200 percent, this effect will prevail. In addition, fare-free transit will not only increase the number of passengers, it will entail a changing structure as well. According to the elasticity figures mentioned above, an above-average increase in peak riders can be assumed. Peak travel is characterized by significantly higher marginal production costs than off-peak travel. This may lead to a blowing-up of the capital stock only to accommodate peak demand. Hence, a considerable increase in average costs will be the consequence. For Templin, the respective costs were estimated at $\cdot 20,000$.

\section{Infrastructure}

Infrastructural benefits can be subdivided into those for flowing and for parking traffic. Due to the minimal modal shift, almost no cost or benefits are to be expected. Road construction cannot be avoided nor are new parking facilities (e.g., for "park and ride") to be built.

\section{Image}

Without doubt, the introduction of the fare-free transit scheme brought much media attention and contributed to the fact that the City of Templin is wellknown in all of Germany and beyond. According to city officials, this advertisement effect was crucial for the 33 percent increase in overnight stays (Stadt Templin 2000). However, it is doubtful that this increase is caused only by popularity of the fare-free bus service. The role of the overall economic growth in the late 1990s should not be neglected. To separate the effects, econometric models should be applied. Hence, Keuchel et al., did not quantify this point. In addition, it has to be pointed out that any advertisement effect is based on the sole position of the City of Templin. With an increasing number of towns introducing the same fare scheme, the marginal advertisement effect will move close to zero. 


\section{Externalities}

Since the introduction of the fare-free transit program in Templin was aimed directly at reducing car-related externalities, this point is of paramount interest, especially in terms of environmental costs and road safety. In the context of farefree transit, the mitigation of environmental costs is caused by the reduction of specific emissions per passenger kilometer (i.e., by a shift from automobiles to less polluting public transportation). Since there is only a small reduction in automobile travel, the environmental effect is very moderate. Keuchel et al., estimate the value of avoided environmental cost (noise, $\mathrm{CO}, \mathrm{NO}_{x^{\prime}} \mathrm{SO}_{2^{\prime}}, \mathrm{HC}$, particulate matter, $\mathrm{CO}_{2}$ ) at $\cdot 5,000$. Because of the chosen money value per unit of pollution, this is the maximum limit.?

In contrast, the benefits with respect to road safety are considerably higher. Because fare-free transit is particularly attractive to pedestrians and bicyclists, it helps to reduce the usage of the most dangerous means of transportation. As shown in Table 3, the fatality ratio as well as the casualty ratio of pedestrians and bicycle riders exceeds that of automobiles and buses by a multiple. However, there is a wide range in the valuation of the prevention of fatalities and casualties. Table 4 shows that the figures used by the German Bundesanstalt für Straßenwesen (BASt) are considerably lower than those used by the British Department of Environment, Transport, and the Regions (DETR). Depending on the value chosen, farefree transit induced cost reductions between $\bullet 43,000$ and 120,000.

Table 3. Fatalities and Casualties by Transportation Mode (per billion passenger kilometer 1999)

\begin{tabular}{|lrrrrr|} 
& Pedestrian & Bicycle & Auto & Bus & Total \\
Fatalities & 39.1 & 25.1 & 8.9 & 0.1 & 9.0 \\
Casualties, serious & 481.6 & 664.4 & 109.4 & 3.1 & 119.5 \\
Casualties, light & 864.8 & 2094.8 & 381.2 & 23.2 & 386.5 \\
\hline
\end{tabular}

Source: Bundesministerium für Verkehr, Bau- und Wohnungswesen , 2000. 
Table 4. The Valuation of Road Accidents

\begin{tabular}{|lrrr|}
\hline \multicolumn{3}{c|}{$\boldsymbol{B A S}^{\boldsymbol{t}}$} & DETR $^{\mathbf{a}}$ \\
\hline Fatalities & $\cdot 1,200,000$ & $\cdot 1,790,000$ & $£ 1,207,670$ \\
Casualties, serious & $\bullet 82,150$ & $\cdot 209,400$ & $£ 141,490$ \\
Casualties, light & $\cdot 3,730$ & $\cdot 20,630$ & $£ 13,940$ \\
\hline
\end{tabular}

Source: Baum and Höhnscheid, 1999; Department of the Environment, Transport and the Regions, 1998. a. Euro values were calculated using the 1998 exchange rate $1.48 \cdot / E$.

To assess whether fare-free transit schemes are an appropriate policy to reduce automobile caused-externalities, the experiences in Templin are very useful. They can be summarized as follows:

- Overall, fare-free transit induced benefits ranging from $\cdot 33,000$ to $\cdot$ 115,000 . On the other hand, total fare revenue of $\bullet 90,000$ had to be abandoned. Whether there is a positive net effect, therefore, depends on the value chosen for reduced environmental and safety costs.

- Even though the abolition of tickets saves costs associated with selling and checking, production costs will increase. This is due to the fact that demand, especially within cost intensive peak times, will increase significantly.

- A considerable modal shift from automobiles to mass transit cannot be achieved. The cross-price elasticity of car travel with respect to bus fares is extremely low. However, a massive shift of pedestrians and bicycle riders to public transportation will increase ridership enormously. In addition, current transit users will ride more often and thus lead to a further increase in service demanded.

- Due to the low substitution potential between automobile travel and mass transit, there is virtually no reduction in automobile-induced environmental costs.

- Almost all induced benefits of fare-free transit schemes are safety related. According to second-best logic this is explained by the existence of a strong undesired side effect: Pedestrians and bicycle riders switch to public transportation and, therefore, escape automobile induced perils. 


\section{Conlcusion and Assessment}

Following the extraordinary growth in automobile travel over the last few decades, transportation externalities have risen to an alarming level. Policies aimed at reducing external costs (e.g., accidents, noise, pollution) can be distinguished into two different approaches: the automobile burdening push policy and the transit favoring pull policy. Against this background the introduction of general fare-free transit schemes appears to experience a renaissance in several European cities; best known are the Belgian Hasselt and the German City of Templin. The staggering increases in ridership in both cities seem to be a clear indication of the overwhelming success of this policy approach. In addition, a study carried out for the German Federal Ministry of Transportation found that the benefits of fare-free transit in Templin could offset the costs. According to the study, the positive net benefit shows that fare-free transit is a viable policy instrument to curb automobile caused externalities. Is this the first step toward a paradigm shift in transportation and environmental policies?

Fare-free schemes are based on the economic theory of the second best. Under first-best conditions, service level and prices of transportation modes were optimized separately; the price should be equal to the respective marginal cost. However, since the private marginal costs of automobile travel lie below the social marginal costs, a welfare improving second-best approach suggests a reduction of transit fares below the first-best optimum. Under particular conditions, this even allows to derive a fare of zero. The objective of this policy is to encourage automobile users to shift to environmentally friendly public transportation. An undesired side effect of fare-free transit, however, may be an increase in the demand by former transit users and the attraction of users of nonmotorized transportation.

This could be confirmed in the City of Templin. A study aimed at quantifying the benefits of fare-free transit found that ridership increased by 1,200 percent. The vast majority of this additional demand consisted of former transit users and attracted pedestrians and bicycle riders. The shift from automobile to transit was only minimal. Depending on the values chosen for intangibles, a positive net benefit may result. This is due mainly to a reduction in fatalities and casualties. Since pedestrians and bicycle riders belong to the most endangered road users, every decrease in these modes will necessarily lead to a reduction of automobile caused costs. The undesired side effect thus becomes the main effect. 
This astounding result appears to be cynical. Should it be the goal of transportation policies to minimize external automobile costs by converting nonmotorized travel into motorized travel? Using the same argument one could introduce a tax on pedestrians and bicycle riders as well. The effect would be more direct and more efficient. In fact, this would be a paradigm shift. Overall, we can state that automobile-caused externalities should not be answered by transit fare reductions. Externalities should better be countered at the source, by internalizing policy approaches.

\section{Endnotes}

${ }^{1}$ For instance, the PDS is demanding fare-free transit for major German cities such as Mainz (200,000 inhabitants) and Munich (1.2 million inhabitants).

${ }^{2}$ This is equal to $\$ 4.1$ billion in 2002 prices.

${ }^{3}$ A comprehensive literature survey is provided by Small (1992).

${ }^{4}$ In general, uncovered costs of accidents or infrastructure can lead to inefficient prices as well. Second-best analyses are to be found, e.g., in Calabresi (1970). The relationship between road accidents and transit pricing was investigated by Allsop and Robertson (1994) and Evans and Morrison (1997). , S. 117 ff. For a comprehensive approach encompassing infrastructure, congestion, environmental, safety, and distribution effects see De Borger et al. (1996).

${ }^{5}$ Compare for instance, the discussion lead in the then German language journal Kyklos by Bohley (1973) and Blankart (1975). Also, in English, Baum (1973).

${ }^{6}$ Encompassing holiday hotel city center, private errands, and other trip purposes.

7 The following values per avoided automobile kilometer driven were assumed: noise - 0.030; $\mathrm{CO}, \mathrm{NO}_{x^{\prime}}, \mathrm{SO}_{2^{\prime}}, \mathrm{HC}$ and particulate matter $\cdot 0.022 ; \mathrm{CO}_{2} \cdot 0.008$. 


\section{References}

Allsop, R. E., and S. A. Robertson. 1994. Road casualties in relation to public transport policy. Journal of Transport Economics and Policy 28: 61-82.

Baum, H. 1973. Free public transport. Journal of Transport Economics and Policy 7: 3-19.

Baum, H. and K. Höhnscheid. 1999. Volkswirtschaftliche Kosten der Personenschäden im Straßenverkehr. Bericht der BASt, Reihe Mensch und Sicherheit, Heft M 102. Bergisch-Gladbach, Germany: BASt.

Blankart, C. B. 1975. Der Nulltarif im Nahverkehr als kollektive und individuelle Entscheidung. Kyklos 28: 154-157.

Bohley, P. 1973. Der Nulltarif im Nahverkehr. Kyklos 26: 113-142.

Bös, D. 1986. Public enterprise economics. Theory and application. Amsterdam and New York: North Holland.

Bundesministerium für Verkehr, Bau- und Wohnungswesen. 2000. Verkehr in Zahlen 2000. Hamburg: Deutscher Verkehrs-Verlag.

Calabresi, G. 1970. The costs of accidents: a legal and economic analysis. New Haven, CT: Yale University Press.

City of Hasselt. 2000. Mobility with an eye on the environment-Hasselt, an example for Europe. Hasselt, Belgium: City of Hasselt.

De Borger, B., I. Mayeres, S. Proost, and S. Wouters. 1996. Optimal pricing of urban passenger transport. Journal of Transport Economics and Policy 30: 31-54.

Department of the Environment, Transport and the Regions. 1998. Highways Economics (Note 1). London: DETR.

Deutscher Bundestag, Unterrichtung durch die Bundesregierung, Bericht der Bundesregierung 1996 über die Entwicklung der Kostenunterdeckung im öffentlichen Personennahverkehr (ÖPNV). Drucksache 13/7552 vom 22.04.97. Prior reports are to be found in Drs. 12/1965 (1992), Drs. 10/6773 (1987), Drs. 9/1658 (1982), Drs. 7/4556 (1976). Bonn: Deutscher Bundestag.

Evans, A. W., and A. D. Morrison. 1997. Incorporating accident risk and disruption in economic models of public transport. Journal of Transport Economics and Policy 31: 117-146. 
Federal Transit Administration (FTA). 2002. National Transit Database. Online: http://www.fta.dot.gov/ntl/database.html. Washington, DC: FTA.

Glaister, S. 1974. Generalised consumer surplus and public transport pricing. The Economic Journal 84: 849-867.

Glaister, S. and D. Lewis. 1978. An integrated fares policy for transport in London. Journal of Public Economics 9: 341-355.

Gómez-Ibáñez, J.1999. Pricing. In Essays in transportation economics and policy. J. Gómez-Ibáñez, W. Tye, and C. Winston, eds. Washington DC: Brookings Institution Press, pp. 99-136.

Hodge, D. C. et al. 1994. Fare-free policy: costs, impacts on transit service, and attainment of transit system goals. Springfield, VA: Washington State Department of Transportation.

Jansson, J. O. 1980. Transport system optimization and pricing. Stockholm: Economic Research Institute at the Stockholm School of Economics.

Keuchel, S., et al. 2000. Kommunaler Nutzen von ÖPNV-Angeboten am Beispiel fahrscheinfreier Tarif-/Finanzierungskonzepte bei Stadtbusverkehren von Klein-und Mittelstädten. Forschungsbericht FE 70.588/99 im Auftrag des Bundesministers für Verkehr, Bau-und Wohnungswesen. Recklinghausen, Germany: Fachhochschule Gelsenkirchen.

Lipsey, R. G., and K. Lancaster. 1956/57. The general theory of second best. Review of Economic Studies 26: 11-32.

Mohring, H. 1972. Optimization and scale economics in urban bus transportation. The American Economic Review 62: 591-604.

Pucher, J., A. Markstedt, and I. Hirschman. 1983. Impacts of subsidies on the costs of urban public transport. Journal of Transport Economics and Policy 17: 155176.

Ratzenberger, R. 1997. Finanzleistungen für den öffentlichen Personennahverkehr. ifo Schnelldienst Nr. 14/97, (Munich: ifo).

Small, K. 1992. Urban transportation economics. Chur, Switzerland: Harwood Academic Publishers.

Stadt Templin. 2000. Fahrscheinfreier Stadtverkehr der Stadt Templin. Informationsschrift. Templin, Germany: Stadt Templin. 
Storchmann, K. 1999. Das Defizit im öffentlichen Personennahverkehr in Theorie und Empirie. (Schriftenreihe des Rheinisch-Westfälischen Instituts für Wirtschaftsforschung, Neue Folge 64. Berlin: Duncker \& Humblodt.

Storchmann, K. 2001. The impact of fuel taxes on public transport-an empirical assessment for Germany. Transport Policy 8: 19-28.

Turvey, R. 1971. Economic analysis and public enterprises. London: Allan \& Unwin.

Turvey, R., and H. Mohring. 1975. Optimal bus fares. Journal of Transport Economics and Policy 9: 280-286.

WIBERA Wirtschaftsberatung AG. 1996. Darstellung der Kosten, Erträge, Betriebsergebnisse und Leistungen des ÖPNV im Jahre 1993 und Vergleich mit vorangegangenen Zeiträumen, insbesondere 1988, getrennt nach Ballungsräumen und übriges Bundesgebiet sowie alten und neuen Bundesländern. Schlußbericht. Untersuchung im Auftrag des Bundesministers für Verkehr, FE-Nr. 70456/94. Düsseldorf, Germany: Wibera.

\section{About the Author}

KaRL Storchmann (Karl-heinz.storchmann@yale.edu) is a lecturer in the Economics Department at Yale University. His main research interests are applied microeconomic issues related to environmental and resource economics, transportation, energy, and agriculture. His most recent articles have appeared in Transport Policy and Agricultural Economics. 